\title{
The Use of Dual Cyclodextrin Chiral Selector Systems in the Enantioseparation of Pharmaceuticals by Capillary Electrophoresis: An Overview
}

\author{
Gabriel Hancu ${ }^{1} \mathbb{C}$, Lajos Attila Papp ${ }^{1, * \mathbb{D}}$, Gergó Tóth ${ }^{2} \mathbb{D}$ and Hajnal Kelemen ${ }^{1}$ \\ 1 Department of Pharmaceutical and Therapeutic Chemistry, Faculty of Pharmacy, University of Medicine, \\ Pharmacy, Science and Technology "George Emil Palade" of Târgu Mureș, 540142 Târgu Mureș, Romania; \\ gabriel.hancu@umfst.ro (G.H.); hajnal.kelemen@umfst.ro (H.K.) \\ 2 Department of Pharmaceutical Chemistry, Semmelweis University, H-1092 Budapest, Hungary; \\ toth.gergo@pharma.semmelweis-univ.hu \\ * Correspondence: lajos.papp@umfst.ro; Tel.: +40-265210407
}

Citation: Hancu, G.; Papp, L.A.; Tóth, G.; Kelemen, H. The Use of Dual Cyclodextrin Chiral Selector Systems in the Enantioseparation of Pharmaceuticals by Capillary Electrophoresis: An Overview. Molecules 2021, 26, 2261. https:// doi.org/10.3390/molecules26082261

Academic Editor: Patrick Chaimbault

Received: 29 March 2021

Accepted: 12 April 2021

Published: 14 April 2021

Publisher's Note: MDPI stays neutral with regard to jurisdictional claims in published maps and institutional affiliations.

Copyright: (c) 2021 by the authors. Licensee MDPI, Basel, Switzerland. This article is an open access article distributed under the terms and conditions of the Creative Commons Attribution (CC BY) license (https:// creativecommons.org/licenses/by/ $4.0 /)$.

\begin{abstract}
Cyclodextrin (CD) derivatives are the most efficient and frequently used chiral selectors (CSs) in capillary electrophoresis (CE). There are situations when the use of a single CD as CS is not enough to obtain efficient chiral discrimination of the enantiomers; in these cases, sometimes this problem can be resolved using a dual CD system. The use of dual CD systems can often dramatically enhance enantioseparation selectivity and can be applied for the separation of many analytes of pharmaceutical interest for which enantioseparation by CE with another CS systems can be problematic. Usually in a dual CD system an anionic CD is used together with a neutral one, but there are situations when the use of a cationic $C D$ with a neutral one or the use of two neutral CDs or even two ionized CDs can be an efficient solution. In the current review we present general aspects of the use of dual CD systems in the analysis of pharmaceutical substances. Several examples of applications of the use of dual CD systems in the analysis of pharmaceuticals are selected and discussed. Theoretical aspects regarding the separation of enantiomers through simultaneous interaction with the two CSs are also explained. Finally, advantages, disadvantages, potential and new direction in this chiral analysis field are highlighted.
\end{abstract}

Keywords: capillary electrophoresis; chiral separation; chiral selectors; cyclodextrins; dual cyclodextrin system

\section{Introduction}

More than half of the pharmaceutical substances currently used in therapy are chiral, however only about $25 \%$ are used in the form of a pure enantiomer. It is known that usually the desired pharmacological effect is restricted to only one of the enantiomers, called eutomer, while the other, called distomer, can be less potent, exhibit different pharmacological activity and sometimes can even be responsible for the adverse effects reported after racemic mixture administration [1].

In the past 25 years the number of pure enantiomers introduced in therapy increased constantly, after the publication in 1992 of FDA regulations regarding the development of new stereoisomeric drugs. Currently the properties of individual enantiomers of a racemic mixture should be studied and characterized individually; and the stereoisomeric composition of an optically active drug must be verified from pharmacokinetic, pharmacologic, and toxicologic point of view [2].

These regulations have major implications in the development of new analytical methods for chiral drug control. The development of efficient and reliable chiral separation techniques is a necessity in assessing enantioselective synthesis, racemization processes, verifying enantiomeric purity and in pharmacokinetic studies [3]. 
Several separation methods and spectral techniques for the analysis of chiral compounds are available including high performance liquid chromatography (HPLC) [4], gas chromatography (GC) [5], thin layer chromatography (TLC) [6], supercritical fluid chromatography (SFC) [7], nuclear magnetic resonance spectroscopy (NMR) [8], circular dichroism spectroscopy or X-ray crystallography [9]. HPLC is the first-choice technique in the routine analysis of chiral pharmaceuticals; however, $\mathrm{CE}$ proved to be in the last decades a viable alternative and a complementary method. There are a series of advantages of using CE in the enantioseparation of optically active pharmaceuticals, related to the rapid method development, high enantioresolution efficiency, low consumption of reagents, analytes, and chiral selectors (CSs), large variety of CSs which can be used and relatively low operational costs. Also, CE is known for its "green" features by comparison with the more frequently used HPLC, as the use of organic solvents is minimum. Furthermore, in CE almost always a direct separation approach is used by simply adding the appropriate CSs into the background electrolyte (BGE) $[10,11]$. Another advantage is represented by the fact that in $\mathrm{CE}$ the migration order of the enantiomers can be reversed based on the nature and characteristics of the CSs, enabling a better understanding and a more practical use of the enantioseparation process [12].

In CE, several types of CSs can be applied (cyclodextrins (CDs), macrocyclic antibiotics, crown ethers, proteins, chiral surfactants, chiral ion pair reagents and other miscellaneous CSs), but by far the most efficient and frequently used are the CD derivatives. Many native and derivatized, neutral and ionized CDs were used successfully during the years for the enantioseparation of a broad spectrum of pharmaceuticals. The advantages of using CDs as CSs in CE are related to their commercial availability, UV transparency, relatively good solubility in aqueous BGEs, and stability over a wide $\mathrm{pH}$ range [13].

CDs are oligosaccharides which form a cone-shaped cavity with 6,7 , or 8 glucopyranose units for $\alpha-, \beta$ - and $\gamma-C D$, respectively. Chiral recognition by CDs is generally driven by inclusion complexation, and by secondary interactions involving $\mathrm{H}$-bonds and dipoledipole interactions with spatially oriented hydroxyl groups and other interactions with the asymmetric carbons of the glucopyranose units $[13,14]$. It is worth to be mentioned that the formation of external type complexes has been also described [15].

One of the inherent advantages of CE methods over chromatographic methods is the fact that CSs can possess their own electrophoretic mobilities and thus several separation schemes can be experimented. Addition of charged groups (carboxyl, sulfonic acid, sulfobutyl) to the basic CD structure allows the separation of neutral analytes. Furthermore, using oppositely charged CDs to the analytes generates counter mobility, and this allows the use of extremely low CS concentration [14,16].

However, the use of a single CD is not always enough for the enantioseparation of some pharmaceuticals. In some cases, enantioresolution can be improved using a dual CD system, consisting usually of a neutral CD (native, derivatized) combined with a charged one (anionic, cationic, amphoteric).

When dual CD systems are used often there are differences in the complexation mechanisms of the two CDs with the enantiomers of the chiral analyte, which are translated into differences between complexation stabilities, chiral identification patterns, and influence on the electrophoretic mobility of the analytes [17].

When separation occurs because of the difference in the complexation constants, enantiomeric separation can be achieved when the mobilities of the complexed and free form of the analyte differ. This situation in the presence of a single CS system is described in the equation below [18]:

$$
\Delta \mu=\frac{\left(\mu_{f}-\mu_{c}\right)\left(K_{R}-K_{S}\right)[C D]}{1+\left(K_{R}+K_{S}\right)[C]+K_{R} K_{S}[C D]^{2}}
$$


where $\mu_{f}$ and $\mu_{c}$ are the electrophoretic mobilities of the free and complexed forms of the analyte, $K_{R}$ and $K_{S}$ are the binding complexation constants of the enantiomers $R$ and $S$, and $[C D]$ is the $C D$ concentration.

In the case of dual CD systems, both CDs can function synergistically. An interesting approach was developed by Fillet et al. to predict enantioseparation when using dual CDs system through a mathematical model. However, this approach is valid only when complexation with the two CDs are independent (excluding mixed complexes) and the analyte: CD complexation ratio is 1:1. The model can be applied for both neutral and charged analytes and CDs [19].

The following equation for the apparent electrophoretic mobility of the enantiomers in dual CD systems is more appropriate [12]:

$$
\mu=\frac{\left(\mu_{f}+\mu_{c 1} K_{c 1}[C D 1]+\mu_{c 2} K_{c 2}[C D 2]\right)}{1+K_{c 1}[C D 1]+K_{c 2}[C D 2]}
$$

where, $\mu$ is the electrophoretic mobility of the enantiomer, $\mu_{f}$ is the electrophoretic mobility of the free form, $\mu_{c 1}$ and $\mu_{c 2}$ are the electrophoretic mobilities of the analyte-CD complexes, $K_{c 1}$ and $K_{c 2}$ are the complexation constants of the enantiomer with CD1 and CD2 and $[C D 1]$ and $[C D 2]$ are the concentration for the two CDs.

Using this kind of equations can be useful because they can predict changes in the selectivity obtained when using dual CD systems. A more detailed discussion on the chiral separation mechanisms in single and dual CD systems can be found in specific review articles published by Dubský et al. [20] and Chankvetadze [21].

The use of a dual CD system assumes optimization of the affinity pattern by selecting the optimum CS for the enantioseparation and of the mobility terms by selecting the optimum concentration of the charged or uncharged CD. An improvement in enantioresolution can be obtained when one CD accelerates the migration of the analytes and the other decelerates it; or sometimes when the affinity pattern of the enantiomers for each $\mathrm{CD}$ is different [22].

The current review focuses on the use of dual CD systems for the analysis of pharmaceuticals and particular features of $C D$ mixture use in $C E$, presenting specific applications of in the enantioseparation of analytes of interest from different matrices.

\section{Applications of Dual CD Systems in the Analysis of Pharmaceuticals}

The first application of dual CD systems in the separation of enantiomers was published in 1994 by Lurie et al. In this study chiral separation of a high number of basic analytes of forensic interest was resolved by $\mathrm{CE}$ using single $\mathrm{CD}$ s and mixtures of neutral and anionic CDs. A dual CD system containing heptakis(2,6-di-O-methyl)- $\beta$-CD $(D M-\beta-C D)$ and sulfobutyl ether $\beta-C D(S B E-\beta-C D)$ proved to be useful for the simultaneous enantioseparation of illicit drugs (amphetamine, methamphetamine, methcathinone, propoxyphene) using a Tris-phosphate BGE at $\mathrm{pH} 2.45$. When using only a single CD some coelutions happened, however using a dual CD all primary amines were separated. This first application has already shown one of the huge benefits of dual CD systems when the goal is the simultaneous separation of enantiomers of several substances. Chiral resolution and migration times of the enantiomers were controlled by adjusting the ratio of the two $\mathrm{CDs}$; the anionic $\mathrm{CD}$ playing the role of counter migrating complexing reagent, while the neutral CD ensured enantiorecognition. An initial theoretical model was developed to characterize the impact of neural and anionic CDs on the chiral resolution of cationic analytes. However, the addition of SBE- $\beta-C D$ resulted in increased tailing and migration times when compared with the use of single DM- $\beta-C D$, probably due to electrodispersion [23].

In another study by Anigbogu et al. the enantiomers of aminoglutethimide were separated in a basic BGE at $\mathrm{pH} 9.0$ using a mixture of neutral $\beta-\mathrm{CD}$ and anionic carboxymethyl$\beta-\mathrm{CD}(\mathrm{CM}-\beta-\mathrm{CD})$. At this $\mathrm{pH}$, aminoglutethimide is neutral and no chiral interactions were observed when using the CDs individually. Apparently the neutral $\beta$-CD provided 
enantioselectivity, while the anionic $C M-\beta-C D$ provided a differential migration rate. The basic $\mathrm{pH}$ of the optimized selected method resulted in a strong electroosmotic flow (EOF), which was accompanied by a short analysis time. The method was compared with a micellar electrokinetic chromatography method (MEKC) at the same $\mathrm{pH}$ using only $\beta-\mathrm{CD}$ as CS which resulted only in partial resolution of the enantiomers and a capillary zone electrophoresis (CZE) technique at acidic $\mathrm{pH}$ (3.0) where small chiral interactions were observed with neutral $\alpha$ - and $\gamma$-CD [24].

Lelièvre et al. developed a CE chiral separation method for arylpropionic acid nonsteroidal anti-inflammatory drug (NSAID) derivatives (carprofen, flurbiprofen, ketoprofen, naproxen, suprofen) using a CD mixture composed of a cationic $C D$, amino- $\beta$-cyclodextrin $\left(\mathrm{NH}_{2}-\beta-\mathrm{CD}\right)$ and a neutral one, trimethyl- $\beta-\mathrm{CD}(\mathrm{TM}-\beta-\mathrm{CD})$ in an acidic BGE at $\mathrm{pH} 2.3$. In this case, interactions with $\mathrm{NH}_{2}-\beta-\mathrm{CD}$, are not stereoselective, however provide the differential migration rates of the enantiomers, while TM- $\beta-C D$ allows the chiral recognition. Also, a theoretical model regarding selectivity was developed for dual CDs separation systems, based on the concept of the apparent constant of complex formation [25].

In another study, regarding chiral NSAIDs (carprofen, fenoprofen, flurbiprofen, ibuprofen, indoprofen, ketoprofen, sulindac, surprofen, tiaprofenic acid) Fillet et al. obtained the baseline enantioseparation by $C E$ using a dual CD selector system containing neutral TM- $\beta$ $\mathrm{CD}$ and the anionic SBE- $\beta-\mathrm{CD}$ at $\mathrm{pH}$ 3.0. In an acidic BGE these analytes are almost neutral, consequently, the use of uncharged CDs alone is inefficient, while the use of charged CDs gave some chiral resolution, which was significantly improved when the dual CD system was applied. In this system the charged CD played the role of the carrier giving the analytes an apparent electrophoretic mobility, while the uncharged CD provided enantioselectivity. Triethanolamine was used as BGE additive to provide a weak EOF; as the anionic CD moved with EOF; remarkably high resolution and relatively short analysis time (less than $15 \mathrm{~min}$ ) for a chiral separation were obtained [26].

Based on the comparison of the two previously mentioned studies we can observe that aryl propionic acid derivative NSAIDs in a mixture can be separated at acidic $\mathrm{pH}$ using a dual CD system. One of the CD should be charged, as both cationic and anionic derivatives were applied to play the carrier role, and the other CD is neutral and is used to improve selectivity.

In a follow-up study, the utility of the previously developed CD system was verified for the enantioseparation of weak acids and neutral compounds (chlormezanone, chlorthalidone, hexobarbital, mephenytoin, mephobarbital, pentobarbital, secobarbital, thiopental). Systems containing DM- $\beta-C D$ and TM- $\beta-C D$ as neutral CDs and CM- $\beta-C D$ and SBE- $\beta-C D$ as anionic ones were tested at different $\mathrm{pH}$ values. All the analytes were baseline enantioseparated at $\mathrm{pH} 3.0$ except for the anxiolytic drug chlormezanone, which was resolved at pH 5.0 using a combination between TM- $\beta-C D$ and CM- $\beta-C D$. Higher resolutions were obtained at $\mathrm{pH} 5.0$ for all the analytes; at this $\mathrm{pH}$, the results obtained when using $\mathrm{CM}-\beta-\mathrm{CD}$ as anionic $C D$ were better than in the case of SBE- $\beta-C D$, due to the substantial increase in the negative charge of $\mathrm{CM}-\beta-\mathrm{CD}$, because of $\mathrm{pH}$ increase from 3.0 to 5.0 [27].

In another study by Fillet et al. the enantioseparation selectivity in dual and single CD CS systems was compared using basic drugs (brompheniramine, chlorpheniramine, dimethindene, ephedrine, verapamil) as model substances. Different CD combinations were tested: CDs with opposite chiral recognition pattern but with the same effect on analyte mobility (CM- $\beta-C D$ and SBE- $\beta-C D)$ and CDs with the same chiral recognition pattern but with opposite effect on analyte mobility (DM- $\beta-C D$ and TM $\beta-C D)$. The use of a CD system in which the CSs have the same effect on the mobility of the analytes, decreased separation efficiency, while the use of a CD system in which the CSs have opposite effect on the mobility of the analytes seem to be beneficial for the separation [28].

It can be seen, that as well as in the case of acidic character compounds, basic drugs can be separated using a dual anionic-neutral CD system. However, in contrast to acidic drugs, basic drugs have their own mobility at acidic $\mathrm{pH}$. Moreover, combination of methylated CD with CM- $\beta-C D$ or SBE- $\beta-C D$ seem to be the most effective dual system. 
CE with a dual CD chiral system was applied by Fillet et al. for the enantioselective determination of $S$-naproxen in tablets. Several single and dual CD systems were applied in a phosphoric acid-triethanolamine BGE at pH 3.0, the best results were obtained when using a mixture of TM- $\beta-C D$ and SBE- $\beta-C D$, similar with the one used previously by the same research group for the enantioseparation of other NSAIDs [24]. The method was validated for the determination of enantiomeric impurity, $R$-naproxen, in a $0.1-2 \%$ range. This method proves the applicability of dual CD systems for the verification of enantiomeric purity of analytes used as pure enantiomers [29].

Meyrig et al. developed a CE method for the enantioseparation of thalidomide and three of its hydroxylated metabolites using a dual CD system composed of native $\beta-C D$ and anionic SBE- $\beta$-CD and a polyacrylamide-coated capillary. The separation of thalidomide and its hydroxylated metabolites by $\mathrm{CE}$ was verified in a previous study by the same research group using four charged CDs, and their combinations with $\beta-C D$, the best results being obtained when using $C M-\beta-C D$, however the simultaneous baseline separation of all the enantiomers was not achieved [30]. In the dual system, SBE- $\beta$-CD exhibited enantioselectivity towards the analytes, while $\beta-C D$ enhances enantioselectivity of recognition in the system. The method was used to characterize biotransformation of thalidomide in vitro by rat liver microsomes. The $C E$ method of the incubated samples together with $X$-ray diffraction was used for the determination of absolute configuration of metabolites and to characterize the stereoselective biotransformation processes. The results support preferential metabolic pathways for $R$ - and $S$-thalidomide [31]. The use of the method was further extended to one additional metabolite, using the same combination of $\beta-C D$ and SBE- $\beta-C D$, carrier mode in which CDs transport the neutral compounds to the detector and polyacrylamide-coated capillary; using this condition the simultaneous separation of all eight enantiomers was resolved. These studies are a good example regarding the bioanalytical application of dual CD systems [32].

In a study published by Abushoffa et al. a single isomer anionic heptakis-6-sulfato$\beta$-cyclodextrin (HS- $\beta$-CD) was used in combination with neutral TM- $\beta$-CD for the CE enantioseparation of arylpropionic acid NSAIDs (fenoprofen, flurbiprofen, ibuprofen, ketoprofen) using a pH 2.5 phosphoric acid-triethanolamine BGE in the reversed polarity mode. The model compounds are acidic and are not ionized at $\mathrm{pH} 2.5$, the use of HS- $\beta-\mathrm{CD}$ as a single CS gave poor resolution, however in dual CD system HS- $\beta$-CD provided the analytes with the suitable mobility while TM- $\beta-C D$ provided enantioselectivity. Affinity constants for the enantiomers with the both CDs were determined, using linear regression in a two-step approach; for HS- $\beta$-CD were calculated in single CD systems while with TM- $\beta$-CD were calculated in dual systems. A mathematical model was developed to predict the best analytical conditions for the CE separation of aryl propionic derivatives in HS- $\beta$-CD-TM- $\beta$-CD dual systems [33].

The same research group applied the use of a mixture of charged CDs for the enantioseparation of the four analytes from the previous study. A combination of two oppositely charged $C D$ derivatives were used; a single isomer cationic $C D$, permethyl-6-monoamino6-monodeoxy- $\beta-C D$ (PMMA- $\beta-C D)$ and an anionic CD, HS- $\beta-C D$ in a phosphoric acidtriethanolamine $\mathrm{BGE}$ at $\mathrm{pH}$ 2.5. Significant improvement in selectivity and resolution was observed, as the two CDs lead independent enantioselective complexation with the analyte enantiomers and exhibit not only opposite effects on the electrophoretic mobility of the analytes but also opposite affinity patterns towards the enantiomers. Binding constants were determined using linear regression method, to predict conditions, giving rise to high selectivity and resolution using the previously developed mathematical models. The use of single isomer CDs allows prediction of the analytical performance (resolution, mobilities) of the method. However, it should also be noted, that these derivatives are much more expensive, and they separation capacity does not exceed the one of randomly substituted CD derivatives [34]. 
Pérez-Maseda et al. developed a CE enantioseparation method for a potential novel NSAID cyclooxygenase-2 (COX-2) inhibitor. The eutomer of this compound is the $S$-enantiomer (E-6232), while the R-enantiomer (E-6231) was considered a chiral impurity; other five degradation impurities were alsoanalyzed. A mixture of DM- $\beta-C D$ and SBE- $\beta-C D$ was used in the chiral separation, the limit of detection (LOD) and limit of quantitation (LOQ) was $0.03 \%$ and $0.1 \%$ of distomer. The use of single SBE- $\beta$-CD proved to be also efficient, however the dual CD system offered advantages in terms of higher enantioresolution and sensitivity [35].

Tábi et al. developed a CE enantioseparation method for deprenyl, an irreversible monoamine oxidase enzyme (MAO) inhibitor and eight of its metabolites, including the active metabolite, $N$-deprenyl oxide. The enantioresolution of all analytes was achieved by using a dual CD system containing DM- $\beta-C D$ in combination with $C M-\beta-C D$ in a Tris-phosphate BGE at $\mathrm{pH}$ 2.7. The method was applied for the determination of deprenyl metabolites in rat urine; stereoselective metabolism of deprenyl was confirmed. This method proves that $\mathrm{CE}$ with dual CD selector system could be an attractive tool for detect and separate chiral metabolites in biological fluids [36].

Lin et al. developed a MEKC enantioseparation method for miconazole, an antifungal agent with an imidazole structure, using a borate-sodium dodecyl sulphate (SDS) BGE at $\mathrm{pH} 9.5$ and a mixture of mono-3-O-phenylcarbamoyl- $\beta-\mathrm{CD}$ (MPC- $\beta$-CD) and $\beta-\mathrm{CD}$ as CS. The separation resolution significantly increased using the dual CD system when compared with the individual CDs alone [37].

An enantioselective method for the verification of chiral purity of a potential antianginal agent with a benzoaxathiepin structure was developed by Beaufor et al. The substance has two chiral centers, consequently four optical isomers, however the eutomer is considered to be the $R, S$-enantiomer, while the $R, R-, S, S$ - and $S, R$-forms are considered to be chiral impurities. The combination of hydroxypropyl- $\gamma-\mathrm{CD}(\mathrm{HP}-\gamma-\mathrm{CD})$ and CM- $\beta-\mathrm{CD}$ was used in the separation added in a phosphate BGE at pH 6.4 [38].

The enantiomeric purity of a basic drug efaroxan, a selective $\alpha$-2-adrenoreceptor antagonist, was verified by CE using a dual CD system. The method published by Lorin et al. uses a mixture of DM- $\beta-C D$ and $C M-\beta-C D$ added in a phosphoric acid-triethanolamine $\mathrm{BGE}$ at $\mathrm{pH}$ 3.0. The method was validated for the enantiomeric impurity determination of the distomer $S$-efaroxan at $0.05 \%$ level [39].

Chu et al. developed a CE enantioselective analysis method for chiral separation of the antiparkinsonian drug rotigotone, a non-ergolinic dopamine receptor agonist and two related chiral impurities. A mixture of methyl- $\beta-C D(M-\beta-C D)$ and sulfated- $\beta-C D$ $(\mathrm{S}-\beta-\mathrm{CD})$ was added in a phosphate buffer at $\mathrm{pH} 2.5$. The LOD and LOQ were 0.003 and $0.01 \mathrm{mM}$ for each enantiomer, respectively [40].

Sungthong et al. developed a stereospecific CE method for the simultaneous determination of optical purity and other related compounds of $S$-citalopram, a selective serotonin reuptake inhibitor (SSRI) antidepressant. Citalopram is used in therapy both as racemic mixture and in the form of its eutomer, S-citalopram. A phosphate BGE at pH 2.5 containing a mixture of native $\beta-C D$ and $S-\beta-C D$ was applied in the enantioseparation. For method optimization a central composite face-centered factorial design was used. During the optimization, the concentration of $\beta-C D$ was kept constant at $0.5 \mathrm{mg} / \mathrm{mL}$ as preliminary experiments revealed not significant effect in the range of $0.5-2 \mathrm{mg} / \mathrm{mL}$; and the effect buffer concentration, applied voltage, temperature and $S \beta-C D$ concentration were studied. The method was validated for the determination of the distomer, $R$-CIT and the enantiomers of an impurity, citadiol. LOD was $0.02 \%$, while LOQ $0.05 \%$ for all compounds reported to a $5 \mathrm{mg} / \mathrm{mL}$ concentration of S-CIT. The method was applied for the determination of chiral purity of S-CIT in bulk substance and tablets. A representative electropherogram for the determination of S-CIT chiral impurities is presented in Figure 1 [41]. 


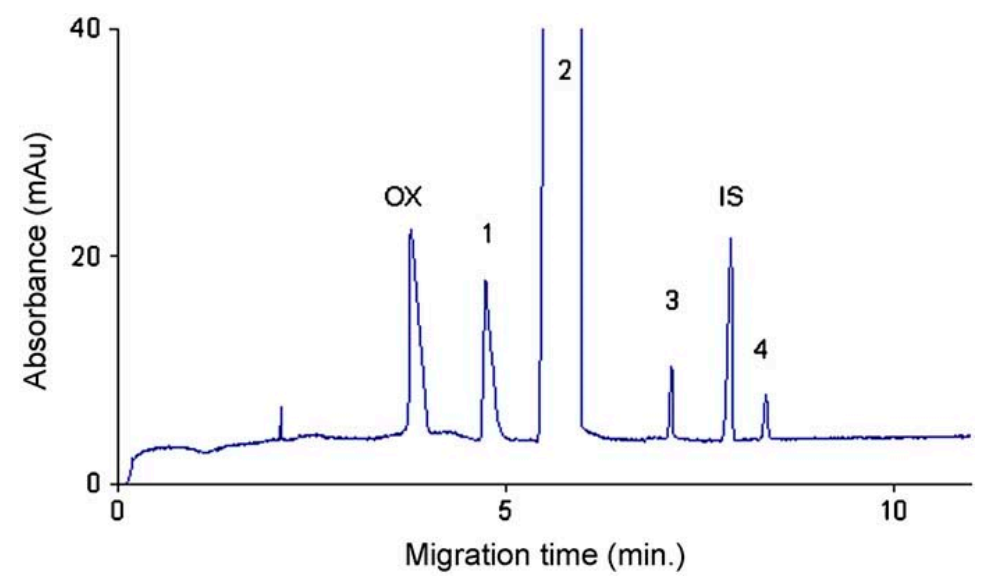

Figure 1. Electropherogram of $5 \mathrm{mg} / \mathrm{mL}$ S-CIT oxalate containing approximately $2.4 \% \mathrm{R}$-CIT and $0.1 \%$ of citadiol enantiomers (1-R-CIT, 2-S-CIT, 3-S-citadiol, 4-R-citadiol, OX-acid oxalic, IS-internal standard (salicylic acid); experimental conditions: $20 \mathrm{mM}$ phosphate BGE, pH 2.5, CS $22 \mathrm{mg} / \mathrm{mL} \mathrm{S}-\beta-\mathrm{CD}+0.5 \mathrm{mg} / \mathrm{mL} \beta-\mathrm{CD},-20 \mathrm{kV}$ voltage; $28^{\circ} \mathrm{C}$ temperature; $50 \mathrm{mbar} / 5 \mathrm{~s}$ injection, detection at $205 \mathrm{~nm}$ ) Reprinted from Sungthong et al. [41] with permission from Elsevier.

A CE chiral separation method for the enantioseparation of three glitazone derivatives (balaglitazone, pioglitazone, rosiglitazone) was developed by Jamali et al. Initially enantiorecognition of DM- $\beta-C D$ and SBE- $\beta-C D$ was investigated in single CD systems at different $\mathrm{pH}$ values. The baseline separation of all analytes was achieved when using a dual CD system composed of the two CDs added to a sodium tetraborate BGE ay $\mathrm{pH}$ 9.70. Optimization of analytical parameters was made using factorial design experiment. ${ }^{1} \mathrm{H}-\mathrm{NMR}$ studies were performed to characterize the $\mathrm{CD}$-analyte interactions; the results showed that SBE- $\beta-C D$ interacts primarily with the basic part of glitazone derivatives while DM- $\beta-C D$ interacts with the phenyl ring [42].

A CE method was used for the simultaneous determination of impurities of dexamphetamine, including levoamphetamine and related substances $(1 S, 2 S)$-norpseudoephedrine, $(1 R, 2 S)$-norephedrine, phenylacetone and phenylacetone oxime. The method developed by Wongwan et al. used a phosphate BGE at $\mathrm{pH} 3.0$ and a combination of SBE- $\beta$-CD and S- $\beta-C D$ as a dual CD selector system. The effect of the degree of substitution of SBE- $\beta$ $\mathrm{CD}$ was investigated. The LOD values were between $0.01-0.02 \%$. This study proves the applicability of dual $C D$ systems containing two anionic $C D$ in the enantioseparation by CE [43].

Lipka et al. worked on the CE enantioseparation of six agonists and antagonists with tetrahydronaphthalenic structures for the melatonin ( $N$-acetyl-5-methoxytryptamin) binding site. The baseline separation was successful using polyethylene oxide dynamically coated capillaries and a dual CD selector system. The composition and concentration of the CD system were optimized systematically. The best results were obtained with a mixture of $\gamma$-CD and highly sulfated- $\beta-\mathrm{CD}$ (HS- $\beta-\mathrm{CD}$ ) in a phosphate buffer at $\mathrm{pH} 2.5$ [44].

A dual CD system composed of 6-monodeoxy-6-mono(3-hydroxy)-propylamino- $\beta$ cyclodextrin (HPA- $\beta-C D$ ) and DM- $\beta-C D$ was used by Wagner et al. for the determination of excitatory amino acids in brain samples by $\mathrm{CE}$ using laser induced fluorescence (LIF) detection. The method was used to separate aspartate and glutamate enantiomers to investigate the putative neuromodulator function of D-aspartate and D-glucose in the central nervous system (CNS). 4-Fluoro-7-nitro-2,1,3-benzoxadiazole was used as fluorescent derivatization agent. The method was applied to analyze brain samples of 1-day-old chickens [45].

Sohajda et al. developed a CE method for the enantioseparation of imperanene, a polyphenolic compound extracted from the plant Imperata cylindrica using CDs as CS. A complex CD screening involving 27 CDs was performed to establish the optimum CS. The best result was obtained using a dual CD system containing 6-monodeoxy-6-mono-(3- 
hydroxy)-propylamino- $\beta$ CD (MPA- $\beta-C D)$ and sulfobutyl-ether- $\gamma-C D(S B E-\gamma-C D)$ added to a borate $\mathrm{BGE}$ at $\mathrm{pH}$ 9.0. The average stoichiometry of the complex was determined with Job's method using NMR-titration, the results showed a 1:1 complex for both enantiomers. One of the curiosities of this study is that the best result was obtained using a dual system containing CDs with opposite charge based on a complex CD screening [46].

Wan Ibrahim et al. developed a MEKC method for the simultaneous determination of three imidazole antifungal drugs (fenticonazole, isoconazole, tioconazole) in a mixture. The baseline separation was obtained using a mixture of two neutral CD, HP- $\gamma-C D$ and DM- $\beta$ $\mathrm{CD}$ added to a phosphate- SDS BGE at $\mathrm{pH}$ 7.0. The use of single CDs gave an incomplete separation, however the mixture of the two neutral CD derivatives was able two separate the six stereoisomers. LOD values for the three analytes ranged from $2.70-7.70 \mathrm{mg} / \mathrm{L}$. The method was applied for the determination of the three drugs in spiked human urine and from pharmaceutical preparations [47].

Separation of five agomelatine analogues, with potential antidepressant effect, was achieved by Lipka et al. using dynamically coated capillary with polyethylene oxide and a dual CD system as CS. The best results were obtained using a phosphate BGE at $\mathrm{pH}$ 2.5 and a mixture of 6 -monodeoxy-6-monoamino- $\beta$-CD (MMA- $\beta-C D)$ and sulfated- $\gamma-C D$ (S- $\gamma$-CD) [48]. Like in previously mentioned study by Sohajda et al. [46], in this study a dual CD system containing positively and negatively charged $\mathrm{CDs}$ at acidic $\mathrm{pH}$ and coated capillary was used to avoid the possible interaction between the CDs and the capillary wall.

Yu et al. verified the applicability of a newly synthetized cationic $C D$, single isomer mono-6-deoxy-6-piperdine- $\beta$-cyclodextrin (PIP- $\beta$-CD), for the enantioseparation by $\mathrm{CE}$ of meptanizol, an opioid-type analgesic with mixed agonist-antagonist effects and three of its intermediates. To enhance chiral resolution a dual CD system containing $\beta-C D$ and PIP- $\beta-C D$ was applied. This example shows the advantage of using dual CD system in the separation of molecules with more chiral centers [49].

The chiral separation of the four stereoisomers of tapentadol, a centrally acting analgesic agent, was described by Znaleziona et al. The best results were obtained when using a mixture of two neutral CDs, hydroxypropyl- $\beta-C D(H P-\beta-C D)$ and HP- $\gamma-C D$ added to a borate BGE at $\mathrm{pH}$ 9.5. HP- $\beta-\mathrm{CD}$ resolved the separation of the $S, R$ - and $R, S$-enantiomers, $\mathrm{HP}-\gamma$-CD resolved the separation of the $S, S$ - and $R, R$-enantiomers; while the use of the dual CD system separated all four stereoisomers. The influence of single and dual CD on the enantioseparation of the tapentadol four stereoisomers is presented in Figure 2 [50].

Melani et al. developed a CE method for the chiral separation of sulpiride, an atypical antipsychotic drug with benzamide structure. Previously the use of a Quality by Design $(\mathrm{QbD})$ strategy was reported by Orlandini et al. for the chiral purity study of the eutomer levosulpiride (S-sulpiride) by $C E$ using a dual CD system composed of $M-\beta-C D$ and S- $\beta$ $\mathrm{CD}$ added in a Britton-Robinson BGE at pH 3.45 [51]. Molecular modelling was used to explain affinity of sulpiride enantiomers towards the two CDs, which were used in the previous study. Two-dimensional rotating-frame nuclear Overhauser effect spectroscopy (2D ROESY-NMR) experiments were applied to characterize complex formation; the results indicated the inclusion of the benzene sulfonamide moiety of sulpiride in the hydrophobic cavity of the CDs [52].

Szabó et al. developed a CE method for the simultaneous determination of four H1 antihistamine derivatives (brompheniramine, chlorpheniramine, cetirizine, promethazine). After an initial CD screening the use of a dual CD system composed of $\beta-C D$ and SBE- $\beta-C D$ added in a phosphate BGE at pH 7.0 was selected as the optimum solution. The two selected CDs showed synergic effect on enantioseparation; resulting in the simultaneous baseline separation of all 8 enantiomers in a short analysis time (less than $8 \mathrm{~min}$ ) with good chiral resolution. Even if chemically related drugs from the same therapeutic class are usually not administered together, the development of generic methods for their simultaneous determination became a tendency in recent years, as it can be applied for the determination of any of these analytes without the need to develop separate methods for each analyte. The method was validated and used for the determination of levocetirizine from tablets [53]. 

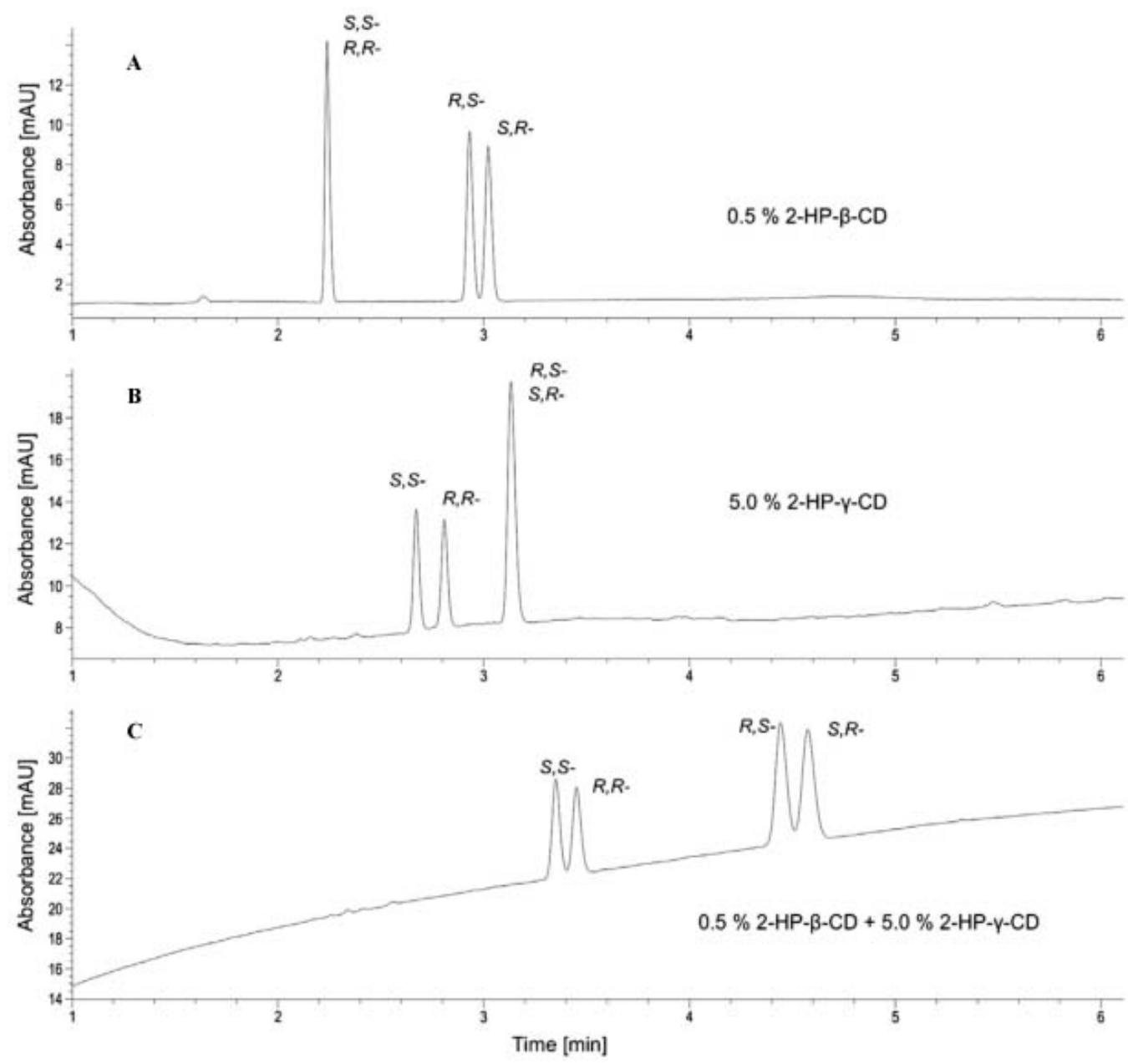

Figure 2. Chiral separation of tapentadol enantiomers by $\mathrm{CE}$ in single and dual $\mathrm{CD}$ systems $((\mathbf{A})-\mathrm{CS} 0.5 \%$ HP- $\beta-C D$; (B)-CS $5 \%$ HP- $\gamma-C D$; (C)-CS $0.5 \%$ HP- $\beta-C D+5 \%$ HP- $\gamma-C D$; experimental conditions: $50 \mathrm{mM}$ phosphate BGE, $\mathrm{pH} 2.5,-25 \mathrm{kV}$ voltage; $15{ }^{\circ} \mathrm{C}$ temperature; $25 \mathrm{mbar} / 5 \mathrm{~s}$ injection, detection at $210 \mathrm{~nm}$ ) Reprinted from Znaleziona et al. [50] with permission from Elsevier.

Nováková et al. reported a CE method for the enantioseparation of leucine and phenylalanine benzothiazole derivatives, with potential antimicrobial effects. Dual CD system consisting of two neutral CDs; $\beta-C D$ with $H P-\beta-C D$ for the leucine derivative and $\beta-\mathrm{CD}$ with HP- $\gamma-\mathrm{CD}$ for the phenylalanine derivative, added in a phosphate BGE at $\mathrm{pH}$ 3.5, proved to be the best solution for the enatioseparation [54].

Delplanques et al. developed a CE method using single and dual CD systems for the enantiomeric and diasteromeric separation of dihydropyridine analogues, with one or two chiral centres. Ten dual CD systems proved to be successful in the separation, among the tested CDs, HS- $\gamma$-CD and SBE- $\beta-C D$ proved to be the most efficient selectors. This work underlines the challenges analysts must overcome in developing chiral separations as there is a large diversity of CDs used as CSs which can be mixed in multiple combinations [55].

The chiral separation method for ketamine metabolites, norketamine, hydroxynorketamine and 5,6-dehydronorketamine by $C E$ was published by Sandbaumhüter et al. The best results were obtained using a mixture of CDs composed of S- $\beta-C D$ and HS- $\gamma-C D$ added to a phosphate BGE at $\mathrm{pH}$ 3.0. A liquid-liquid extraction (LLE) was used for sample preparation. The method was applied to analyze plasma samples from dogs and horses after i.v. ketamine administration and in an in vitro study in which ketamine was incubated with equine liver microsome [56]. 
Papp et al. developed a CE method for the enantioseparation of two proton pump inhibitors (PPI) (lansoprazole, rabeprazole). Single and dual CD systems were screened in a preliminary analysis. A mixture containing $\gamma-C D$ and SBE- $\beta-C D$ was selected and added in a phosphate BGE at $\mathrm{pH}$ 7.0. An experimental design approach was used for method optimization, a fractional factorial screening design followed by a central composite design. The optimum ratio of the two CDs was different for lansoprazole and rabeprazole, respectively. The method was validated and applied for the determination of distomers (S-lansoprazole, $S$-rabeprazole) as chiral impurities in dexlansoprazole and dexrabeprazole samples [57].

A representative electropherogram from our own collection which illustrates the increase of chiral resolution and decrease of analysis time using a dual CD system composed of $\gamma-C D$ and SBE- $\beta-C D$ in the case of rabeprazole is presented in Figure 3.
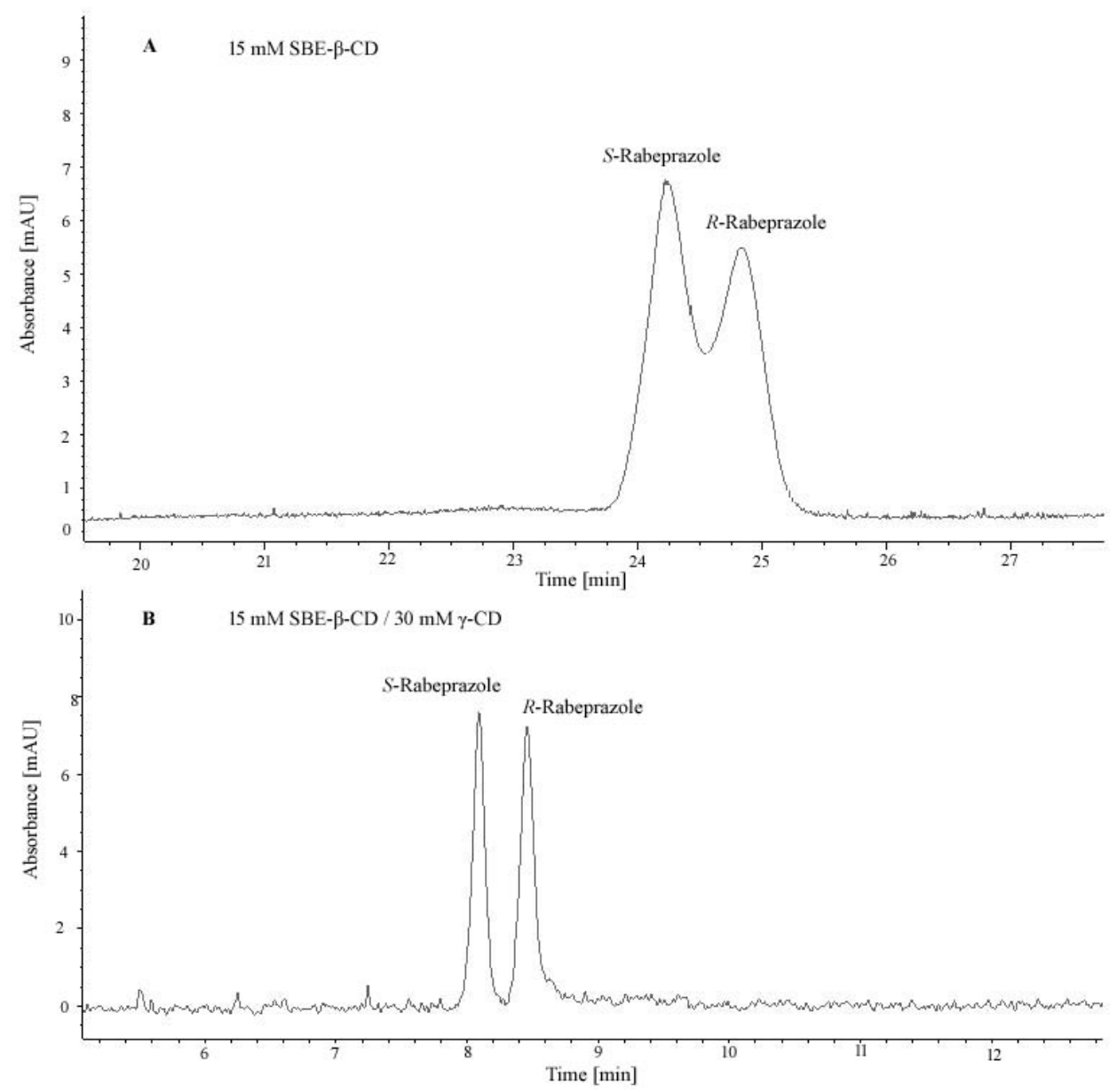

Figure 3. Chiral separation of rabeprazole enantiomers by $\mathrm{CE}$ in single and dual CD systems ((A)—CS $15 \mathrm{mM}$ SBE- $\beta-C D,(\mathbf{B})-\mathrm{CS} 15 \mathrm{mM}$ SBE- $\beta-C D / 30 \mathrm{mM} \gamma$-CD; experimental conditions: $25 \mathrm{mM}$ phosphate $\mathrm{BGE}, \mathrm{pH}=7.0,+20 \mathrm{kV}$ voltage; $18{ }^{\circ} \mathrm{C}$ temperature; $50 \mathrm{mbar} / 3 \mathrm{~s}$ injection, detection at $210 \mathrm{~nm}$ ).

Harnisch et al. published a CE method for the simultaneous determination of chiral and achiral purity of $S$-dapoxetine, a selective serotonin reuptake inhibitor (SSRI), regarding the distomer $R$-dapoxetine and structurally related impurities. For the optimization of the analytical method an initial fractional factorial design was applied followed by face centered central composite design. The optimum CD CS system contained DM- $\beta-C D$ and S- $\gamma-\mathrm{CD}$ added to a phosphate BGE at $\mathrm{pH}$ 6.3. The method was validated and applied for the analysis of dapoxetine in tablets [58].

The same methodology was applied by Krait et al. for the determination of chiral purity of dextromethorphan, a centrally active antitussive drug, regarding its distomer, 
levometorphan. A dual CD system containing $\mathrm{M}-\beta-\mathrm{CD}$ and $\mathrm{S}-\beta-\mathrm{CD}$ added in a phosphate $\mathrm{BGE}$ at $\mathrm{pH} 6.5$ was used. An initial fractional factorial design followed by a face centered central composite design was used for method optimization. The method was validated and applied for the analysis of dextromethorphan in capsules [59].

Casado et al. applied CE method with a dual CD system for the simultaneous enantioseparation of six phenoxy acid herbicides from a complex mixture. The CD CS system contained two neutral derivatives HP- $\beta$ CD and TM- $\beta-C D$ added in a phosphate BGE at $\mathrm{pH}$ 7.0. The method development was based on a previously published theoretical model proposed by Dubský et al., which permits prediction of what happens in a dual CD system by performing individual measurements with each $\mathrm{CD}$ individually at different concentration levels [60]. The results confirmed the validity of the theoretical model, improving enantiomeric resolution and reducing migration times of the analytes, enabling to establish the most favorable proportion between the two CDs. Additionally, the apparent complexation constants between enantiomers and both CDs were calculated [61].

The previously described methods analytical conditions are summarized in Table 1.

Table 1. Electrophoretic conditions for the enantioseparation of drugs using dual cyclodextrin systems.

\begin{tabular}{|c|c|c|c|}
\hline Electrophoretic Conditions & Chiral Selector & Analyte & Reference \\
\hline $\begin{array}{l}25 \text { mM Tris-phosphoric acid, pH } 2.45,10 \% \\
\text { methanol, } 30 \mathrm{kV}, 30{ }^{\circ} \mathrm{C}, \mathrm{UV} 210 \mathrm{~nm}\end{array}$ & $5 \mathrm{mM}$ DM- $\beta-\mathrm{CD}, 1 \mathrm{mM}$ SBE- $\beta-\mathrm{CD}$ & $\begin{array}{c}\text { amphetamine, metamphetamine, } \\
\text { methcathinone, propoxyphene- } \\
\text { bulk substances }\end{array}$ & {$[23]$} \\
\hline $\begin{array}{l}10 \mathrm{mM} \text { phosphate- } 6 \mathrm{mM} \text { borax, } \mathrm{pH} 9.0,50 \% \\
\text { methanol, } 10 \mathrm{kV}, \mathrm{UV} 205 \mathrm{~nm}\end{array}$ & $1 \mathrm{mM} \beta-\mathrm{CD}, 5 \mathrm{mM} C \mathrm{CM}-\beta-\mathrm{CD}$ & aminogluthetimide-bulk substance & [24] \\
\hline $\begin{array}{l}34 \mathrm{mM} \text { phosphoric acid, pH 2.30, } 20 \mathrm{kV}, 25^{\circ} \mathrm{C}, \\
\mathrm{UV} 240 \mathrm{~nm} \text { (calprofen, flurbiprofen), } 210 \mathrm{~nm} \\
\text { (ketoprofen), } 230 \mathrm{~nm} \text { (naproxen), } \\
254 \mathrm{~nm} \text { (suprofen) }\end{array}$ & $\begin{array}{l}10 \mathrm{mM} \text { TM- } \beta-\mathrm{CD}, 20 \mathrm{mM} \\
\mathrm{NH}_{2}-\beta-\mathrm{CD}\end{array}$ & $\begin{array}{l}\text { carprofen, flurbiprofen, ketoprofen, } \\
\text { naproxen, suprofen-bulk substances }\end{array}$ & [25] \\
\hline $\begin{array}{l}100 \mathrm{mM} \text { phosphoric acid-triethanolamine, } \\
\text { pH 3.0, }-25 \mathrm{kV}, 25^{\circ} \mathrm{C}, 230 \mathrm{~nm} \text { (carprofen, } \\
\text { fenoprofen, flurbiprofen), } 210 \mathrm{~nm} \text { (ibuprofen), } \\
280 \mathrm{~nm} \text { (indoprofen, ketoprofen, sulindac, } \\
\text { suprofen, tiaprofenic acid). }\end{array}$ & $\begin{array}{l}15 \mathrm{mM} \text { TM- } \beta-C D, 5 \mathrm{mM} \\
\text { SBE- } \beta-C D\end{array}$ & $\begin{array}{l}\text { carprofen, fenoprofen, flurbiprofen, } \\
\text { ibuprofen, indoprofen, ketoprofen, sulindac, } \\
\text { surprofen, tiaprofenic } \\
\text { acid-bulk substances }\end{array}$ & [26] \\
\hline $\begin{array}{c}100 \mathrm{mM} \text { phosphoric acid-triethanolamine, } \\
\text { pH 3.0, - } 25 \mathrm{kV}, 25^{\circ} \mathrm{C} \text {, UV } 210 \mathrm{~nm} \\
100 \mathrm{mM} \text { phosphoric acid-triethanolamine, } \\
\text { pH 5.0,-25 kV, } 25^{\circ} \mathrm{C} \text {, UV } 210 \mathrm{~nm}\end{array}$ & $\begin{array}{l}10 \mathrm{mM} \text { TM- } \beta-\mathrm{CD}(\mathrm{DM}-\beta-\mathrm{CD}) \\
5 \mathrm{mM} \text { SBE- } \beta-\mathrm{CD} \\
10 \mathrm{mM} \text { TM- } \beta-\mathrm{CD}(\mathrm{DM}-\beta-\mathrm{CD}) \\
10 \mathrm{mM} \text { CM- } \beta-\mathrm{CD}\end{array}$ & $\begin{array}{l}\text { chlormezanone, chlorthalidone, } \\
\text { hexobarbital, mephenytoin, mephobarbital, } \\
\text { pentobarbital, secobarbital, } \\
\text { thiopental—bulk substances }\end{array}$ & [27] \\
\hline $\begin{array}{c}100 \mathrm{mM} \text { phosphoric acid, } \mathrm{pH} 3.0,25 \mathrm{kV}, 25^{\circ} \mathrm{C} \text {, } \\
\text { UV } 210 \mathrm{~nm}\end{array}$ & $\begin{array}{c}10 \mathrm{mM} \text { TM- } \beta-C D, 5 \mathrm{mM} \\
\text { CM- } \beta-C D\end{array}$ & $\begin{array}{l}\text { brompheniramine, chlorpheniramine, } \\
\text { dimethindene, ephedrine, } \\
\text { verapamil_bulk substances }\end{array}$ & [28] \\
\hline $\begin{array}{l}100 \mathrm{mM} \text { phosphoric acid-triethanolamine, } \\
\mathrm{pH} 3.0,-25 \mathrm{kV}, 25^{\circ} \mathrm{C}, \mathrm{UV} 210 \mathrm{~nm}\end{array}$ & $\begin{array}{l}20 \mathrm{mM} \text { TM- } \beta-C D, 5 \mathrm{mM} \\
\text { SBE- } \beta-C D\end{array}$ & naproxen chiral purity-tablets & [29] \\
\hline $\begin{array}{l}5 \mathrm{mM} \text { ammonium acetate, } \mathrm{pH} 4.5,-30 \mathrm{kV} \text {, } \\
25{ }^{\circ} \mathrm{C}, \mathrm{UV} 210 \mathrm{~nm}\end{array}$ & $\begin{array}{c}12 \mathrm{mg} / \mathrm{mL} \beta-C D, 12 \mathrm{mg} / \mathrm{mL} \\
\text { SBE- } \beta-C D\end{array}$ & $\begin{array}{l}\text { thalidomide, } 3 \text { hydroxylated } \\
\text { metabolites-rat liver fractions }\end{array}$ & [31] \\
\hline $\begin{array}{l}100 \mathrm{mM} \text { phosphoric acid-triethanolamine, } \\
\text { pH } 2.5,-25 \mathrm{kV}, 25^{\circ} \mathrm{C}, \mathrm{UV} 214 \mathrm{~nm}\end{array}$ & 20 mM TM- $\beta-C D, 3$ mM HS- $\beta-C D$ & $\begin{array}{l}\text { fenoprofen, flurbiprofen, ibuprofen, } \\
\text { ketoprofen-bulk substances }\end{array}$ & [33] \\
\hline $\begin{array}{c}100 \mathrm{mM} \text { phosphoric acid-triethanolamine, } \\
\text { pH } 2.5,25 \mathrm{kV}, 25^{\circ} \mathrm{C}, \mathrm{UV} 214 \mathrm{~nm}\end{array}$ & $\begin{array}{l}4 \mathrm{mM} \text { HS- } \beta-C D, 18 \mathrm{mM} \\
\text { PMMA- } \beta-C D\end{array}$ & $\begin{array}{l}\text { fenoprofen, flurbiprofen, ibuprofen, } \\
\text { ketoprofen-bulk substances }\end{array}$ & [34] \\
\hline $\begin{array}{c}50 \mathrm{mM} \text { sodium tetraborate, } 30 \% \text { methanol, } \\
\mathrm{pH} 9.2,30 \mathrm{kV}, 20^{\circ} \mathrm{C}, \mathrm{UV} 315 \mathrm{~nm}\end{array}$ & $\begin{array}{c}0.5 \mathrm{mM} \text { DM- } \beta-\mathrm{CD}, 7.1 \mathrm{mM} \text { SBE- } \\
\beta-\mathrm{CD}\end{array}$ & $\begin{array}{l}\text { COX-2 inhibitor, chiral } \\
\text { impurities-bulk substances }\end{array}$ & [35] \\
\hline $\begin{array}{c}20 \mathrm{mM} \text { Tris-phosphate, } \mathrm{pH} 2.7,25 \mathrm{kV}, 20^{\circ} \mathrm{C} \text {, } \\
\text { UV } 214 \mathrm{~nm}\end{array}$ & $9 \mathrm{mM} D \mathrm{DM}-\beta-\mathrm{CD}, 0,5 \% \mathrm{CM}-\beta-\mathrm{CD}$ & deprenyl, deprenyl metabolites-rat urine & {$[36]$} \\
\hline $\begin{array}{c}50 \mathrm{mM} \text { sodium tetraborate, } 50 \mathrm{mM} \text { SDS, } 1 \mathrm{M} \\
\text { urea, } \mathrm{pH} 9.5, \mathrm{UV} 214 \mathrm{~nm}\end{array}$ & $15 \mathrm{mM} \beta-\mathrm{CD}, 15 \mathrm{mM}$ MPC- $\beta-\mathrm{CD}$ & miconazole-bulk substance & [37] \\
\hline $\begin{array}{c}30 \mathrm{mM} \text { phosphate, } \mathrm{pH} 6.4,30 \mathrm{kV}, 20^{\circ} \mathrm{C}, \\
\text { UV } 214 \mathrm{~nm}\end{array}$ & $\begin{array}{c}10 \mathrm{mM} \mathrm{HP}-\gamma-\mathrm{CD}, 10 \mathrm{mM} \text { CM- } \\
\beta-\mathrm{CD}\end{array}$ & $\begin{array}{l}\text { benzoaxathiepin antianginal agent, chiral } \\
\text { impurities_-bulk substances }\end{array}$ & [38] \\
\hline $\begin{array}{c}100 \mathrm{mM} \text { phosphoric acid-triethanolamine, } \\
\text { pH 3.0, } 20 \mathrm{kV}, 25^{\circ} \mathrm{C} \text {, UV } 214 \mathrm{~nm}\end{array}$ & $\begin{array}{c}7,5 \mathrm{mM} \text { DM- } \beta-C D, 3 \mathrm{mM} \\
\text { CM- } \beta-C D\end{array}$ & efaroxan, chiral impurity_-bulk substance & {$[39]$} \\
\hline
\end{tabular}


Table 1. Cont.

\begin{tabular}{|c|c|c|c|}
\hline Electrophoretic Conditions & Chiral Selector & Analyte & Reference \\
\hline $\begin{array}{c}100 \mathrm{mM} \text { sodium phosphate buffer, } \mathrm{pH} 2.5 \text {, } \\
-20 \mathrm{kV}, 20^{\circ} \mathrm{C} \text {, UV } 200 \mathrm{~nm}\end{array}$ & $\begin{array}{c}2 \%(w / v) \mathrm{M}-\beta-\mathrm{CD}, 2 \%(w / v) \\
\mathrm{S}-\beta-\mathrm{CD}\end{array}$ & $\begin{array}{l}\text { rotigotone, chiral } \\
\text { impurities-bulk substances }\end{array}$ & [40] \\
\hline $\begin{array}{c}20 \mathrm{mM} \text { phosphate, pH } 2.5,-20 \mathrm{kV}, 28^{\circ} \mathrm{C}, \\
\text { UV } 205 \mathrm{~nm}\end{array}$ & $\begin{array}{l}0.5 \mathrm{mg} / \mathrm{mL} \beta-\mathrm{CD}, 22 \mathrm{mg} / \mathrm{mL} \\
\text { S- } \beta-\mathrm{CD}\end{array}$ & $\begin{array}{l}\text { S-citalopram—chiral purity-bulk } \\
\text { substance, tablets }\end{array}$ & [41] \\
\hline $\begin{array}{l}50 \mathrm{mM} \text { sodium tetraborate, } \mathrm{pH} 9.7,15 \mathrm{kV}, 30^{\circ} \mathrm{C} \text {, } \\
\text { UV } 200 \mathrm{~nm}\end{array}$ & $\begin{array}{l}3 \mathrm{mM} \text { DM- } \beta-\mathrm{CD}, 12 \mathrm{mM} \\
\text { SBE- } \beta-\mathrm{CD}\end{array}$ & $\begin{array}{l}\text { balaglitazone, pioglitazone, } \\
\text { rosiglitazone-bulk substance }\end{array}$ & [42] \\
\hline $\begin{array}{c}50 \mathrm{mM} \text { phosphate, } \mathrm{pH} 3.0,-10 \mathrm{kV}, 20^{\circ} \mathrm{C}, \\
\text { UV } 200 \mathrm{~nm}\end{array}$ & $\begin{array}{l}80 \mathrm{mg} / \mathrm{mL} \text { SBE- } \beta-C D, 25 \mathrm{mg} / \mathrm{mL} \\
\text { S- } \beta-C D\end{array}$ & $\begin{array}{l}\text { dexamphetamine -chiral } \\
\text { purity_bulk substances }\end{array}$ & [43] \\
\hline $\begin{array}{l}25 \mathrm{mM} \text { phosphoric acid-triethanolamine, } \\
\mathrm{pH} 2.5,25 \mathrm{kV}, 20^{\circ} \mathrm{C}, \mathrm{UV} 190 \mathrm{~nm}\end{array}$ & $\begin{array}{c}10 \mathrm{mM} \gamma-\mathrm{CD}, 1.5 \%(w / v) \\
\text { HS- } \beta \text {-CD }\end{array}$ & $\begin{array}{l}\text { agonist and antagonist melatoninergic } \\
\text { ligands_-bulk substances }\end{array}$ & [44] \\
\hline $\begin{array}{l}75 \mathrm{mM} \text { sodium tetraborate, } \mathrm{pH} 9.0,30 \mathrm{kV}, 20^{\circ} \mathrm{C} \text {, } \\
\text { UV } 210 \mathrm{~nm}\end{array}$ & $\begin{array}{l}10 \mathrm{mM} \text { MPA- } \beta-\mathrm{CD}, 12.5 \mathrm{mM} \\
\text { SBE- } \gamma-\mathrm{CD}\end{array}$ & imperanene & [46] \\
\hline $\begin{array}{l}35 \mathrm{mM} \text { phosphate, } 50 \mathrm{mM} \text { SDS, pH 7.0, } 15 \% \\
(v / v) \text { acetonitrile, } 27 \mathrm{kV}, 20^{\circ} \mathrm{C} \text {, UV } 210 \mathrm{~nm}\end{array}$ & $\begin{array}{c}35 \mathrm{mM} \mathrm{HP}-\gamma-\mathrm{CD}, 10 \mathrm{mM} \\
\text { DM- } \beta-C D\end{array}$ & $\begin{array}{l}\text { fenticonazole, isoconazole, } \\
\text { tioconazole-spiked urine sample, } \\
\text { pharmaceutical preparation }\end{array}$ & [47] \\
\hline $\begin{array}{c}25 \mathrm{~mm} \text { phosphate, } \mathrm{pH} 2.5,25 \mathrm{kV}, 25^{\circ} \mathrm{C}, \\
\text { UV } 227 \mathrm{~nm}\end{array}$ & $\begin{array}{l}10 \mathrm{mM} \text { MMA- } \beta-\mathrm{CD}, 5 \%(w / v) \\
\text { S- } \gamma-\mathrm{CD}\end{array}$ & agomelatine analogues—bulk substances & [48] \\
\hline $\begin{array}{l}20 \mathrm{mM} \text { phosphate, } \mathrm{pH} 3.0,20 \mathrm{kV}, 20^{\circ} \mathrm{C}, \mathrm{UV} 237, \\
271 \mathrm{~nm}\end{array}$ & $40 \mathrm{mM}$ HP- $\beta-\mathrm{CD}, 5 \mathrm{mM}$ PIP- $\beta-\mathrm{CD}$ & $\begin{array}{l}\text { meptanizol, } 4 \text { intermediates- } \\
\text { bulk substances }\end{array}$ & [49] \\
\hline $\begin{array}{l}50 \mathrm{mM} \text { phosphate, } \mathrm{pH} 2.5,25 \mathrm{kV}, 15^{\circ} \mathrm{C}, \\
\text { UV } 210 \mathrm{~nm}\end{array}$ & $\begin{array}{l}0.1 \%(w / v) \mathrm{HP}-\beta-\mathrm{CD}, 0.5 \%(w / v) \\
\text { HP- } \gamma-\mathrm{CD}\end{array}$ & tapentadol—bulk substances & [50] \\
\hline $\begin{array}{c}5 \mathrm{mM} \text { Britton Robinson buffer, pH 3.45, } 14 \mathrm{kV}, \\
16^{\circ} \mathrm{C}, \mathrm{UV} 214 \mathrm{~nm}\end{array}$ & $34 \mathrm{mM}$ M- $\beta-\mathrm{CD}, 10 \mathrm{mM}$ S- $\beta-\mathrm{CD}$ & sulpiride—bulk substance & [52] \\
\hline $\begin{array}{c}25 \mathrm{mM} \text { phosphate, } \mathrm{pH} 7.0,25 \mathrm{kV}, 25^{\circ} \mathrm{C} \text {, } \\
\text { UV } 214 \mathrm{~nm}\end{array}$ & $10 \mathrm{mM} \beta-\mathrm{CD}, 15 \mathrm{mM}$ SBE- $\beta-\mathrm{CD}$ & $\begin{array}{l}\text { brompheniramine, chlorpheniramine, } \\
\text { cetirizine, promethazine-bulk } \\
\text { substances, tablets }\end{array}$ & [53] \\
\hline $\begin{array}{c}100 \mathrm{mM} \text { phosphate, } \mathrm{pH} 3.5,24 \mathrm{kV}, 17^{\circ} \mathrm{C} \text {, } \\
\text { UV } 220 \mathrm{~nm}\end{array}$ & $\begin{array}{c}10 \mathrm{mM} \beta \mathrm{CD}, 10 \mathrm{mM} \text { HP- } \beta-\mathrm{CD} \\
\text { (leucine) } \\
10 \mathrm{mM} \beta \mathrm{CD}, 10 \mathrm{mM} \mathrm{HP}-\gamma-\mathrm{CD} \\
\text { (phenylalanine) }\end{array}$ & $\begin{array}{l}\text { benzothiazole derivatives of leucine and } \\
\text { phenylalanine—-bulk substances }\end{array}$ & [54] \\
\hline $\begin{array}{l}50 \mathrm{mM} \text { phosphate, } \mathrm{pH} 3.0,20 \mathrm{kV}, 20^{\circ} \mathrm{C}, \\
\text { UV } 200 \mathrm{~nm}\end{array}$ & $5 \mathrm{mM}$ S- $\beta-\mathrm{CD}, 0.1 \% \mathrm{~b}$ HS- $\gamma-\mathrm{CD}$ & ketamine metabolites-plasma samples & [56] \\
\hline $\begin{array}{c}25 \mathrm{mM} \text { phosphate, } \mathrm{pH} 7.0,20 \mathrm{kV}, 18^{\circ} \mathrm{C} \text {, } \\
\text { UV } 210 \mathrm{~nm}\end{array}$ & $\begin{array}{c}20 \mathrm{mM} \gamma \text {-CD, } 10 \mathrm{mM} \text { SBE- } \beta-\mathrm{CD} \\
\text { (lansoprazole) } \\
30 \mathrm{mM} \gamma-\mathrm{CD}, 15 \mathrm{mM} \text { SBE- } \beta-\mathrm{CD} \\
\text { (rabeprazole) }\end{array}$ & lansoprazole, rabeprazole—bulk substances & [57] \\
\hline $\begin{array}{c}50 \mathrm{mM} \text { phosphate, } \mathrm{pH} 6.3,20 \mathrm{kV}, 20^{\circ} \mathrm{C}, \\
\text { UV } 210 \mathrm{~nm}\end{array}$ & $\begin{array}{l}40.2 \mathrm{mg} / \mathrm{mL} \mathrm{DM}-\beta-\mathrm{CD}, 45 \mathrm{mM} \\
\text { S- } \gamma-\mathrm{CD}\end{array}$ & $\begin{array}{l}\text { dapoxetine-chiral purity-bulk } \\
\text { substance, tablets }\end{array}$ & [58] \\
\hline $\begin{array}{l}30 \mathrm{mM} \text { phosphate, } \mathrm{pH} 6.5,9 \mathrm{kV}, 15^{\circ} \mathrm{C} \text {, } \\
\text { UV } 200 \mathrm{~nm}\end{array}$ & $\begin{array}{c}14 \mathrm{mg} / \mathrm{mL} \mathrm{M}-\beta-\mathrm{CD}, 16 \mathrm{mg} / \mathrm{mL} \\
\text { S- } \beta-C D\end{array}$ & $\begin{array}{l}\text { dextrometorphan—chiral purity-bulk } \\
\text { substance, capsules }\end{array}$ & [59] \\
\hline $\begin{array}{c}50 \mathrm{mM} \text { phosphate, } \mathrm{pH} 7.0,25 \mathrm{kV}, 15^{\circ} \mathrm{C}, \\
\text { UV } 200 \mathrm{~nm}\end{array}$ & $\begin{array}{c}4 \mathrm{mM} \mathrm{HP}-\beta-\mathrm{CD}, 16 \mathrm{mM} \\
\text { TM- } \beta-\mathrm{CD}\end{array}$ & phenoxy acid herbicides—bulk substances & [61] \\
\hline
\end{tabular}

\section{Discussion}

To choose an efficient dual CD system, and explain chiral separation, analysts must consider both chiral interactions which occurs at molecular level and chiral recognition which leads to chiral discrimination. Consequently, both mobility and affinity effects must be taken into consideration and an explanation about affinity patterns that generates increased enantioseparation may be drawn depending on the effect of both CSs on the electrophoretic mobility of the analyte enantiomers.

In some situations, an increase in the selectivity of enantioresolution can be observed when changing from a single CD CS system to a dual CD system. Also, sometimes, the intrinsic chiral separation mechanism can be better understood when a dual CD system is applied as it is possible to define selectivity whether complexing agents are considered separately or all together. 
Several combinations of CDs can be used in practice: combinations between a neutral $\mathrm{CD}$ with a charged one, between two charged CDs with the same charge or between two neutral CDs $[13,14,16]$.

Analyte-CD complexation is the main trigger that leads to enantiomer separation by CE when this leads to differences in mobility between the free and complexed formed of the analytes and stability differences between the complexes formed by the CD with the enantiomers of the analyte. In the case of charged CDs, they have their own electrophoretic mobility, and can be used as carriers for the separation of neutral and ionizable analytes in uncharged forms $[17,19]$.

In some dual CD systems, the chiral discrimination capacity of one CD can lead to enantioresolution only in the presence of the second CD. For example, if we have an uncharged chiral analyte, its enantiomers can exhibit chiral interaction with a neutral CD without significant enantioresolution because of the small mobility differences between the free and the complexed forms. When a charged CD is added to the BGE, it can provide an apparent electrophoretic mobility to the analyte, which increases enantioresolution; even if the interactions with the charged CD are not enantioselective $[17,19,62]$.

In other dual CD systems, the interactions with the two CDs can be both enantioselective, and have opposite effects on the migration of enantiomers, one CD accelerates while the other decelerates them, in this case enantioselectivity is obtained if the affinity patterns of the enantiomers towards the CDs are different. The same condition must be met, if one of the CDs has little effect on the electrophoretic mobility of the analyte, as in the case of an uncharged analyte and a neutral CD. A mixture of two CDs exhibiting the same effect on analyte mobility, as both CDs accelerate or decelerate migration of the enantiomers, seem to be inefficient in the separation $[17,19]$.

But in another hand, the variations in chiral selectivity observed when using dual CD systems are not always explainable; in some situations, the two CDs can have synergistic or antagonistic effects on the chiral resolution, which makes the overall process unpredictable.

To obtain information about complex stoichiometry, binding constants, stereoselectivity or intermolecular analyte-CD interactions other instrumental techniques such as NMR, MS or X-ray crystallography can be used. Molecular modelling can also be a valuable tool in establishing analyte-CD complex structure and mechanism of enantiorecognition $[63,64]$.

Initially a trial-error strategy was applied in choosing the optimum CD for the separation, however in the past 20 years the theory enantioseparation in dual CD mixtures has been explained and understood. Theoretical mathematical models have been developed and can be used as feasible practical approaches in chiral method development $[22,60,65]$.

Also, the use of $\mathrm{QbD}$ principles and design of experiments (DoE) represents a new strategy for the development of CE separation methods suitable for chiral analysis [51,66]

It is essential that choice of the optimum CD mixture as CSs, should be complemented using the right ratio between the two CD and DoE is an efficient tool to establish this with a minimum number of experiments $[57,66,67]$.

It should be noted that even if in CE enantioseparations usually dual CD systems are used, CD may be combined sometimes also with other CSs (chiral ionic liquid, chiral antibiotic, polysaccharide, crown ethers and others) or rarely combined CS system without CDs can be applied [10,68].

\section{Conclusions}

There is only one review published in literature regarding the specific use of CD dual systems in CE for the analysis of pharmaceuticals, this review was published in 2000 by Fillet et al. [13]. However, the application in the pharmaceutical field of dual CD systems has broadened and separation mechanism involved in chiral discrimination has been more profoundly understood in the past twenty years.

Of course, there are a series of reviews published in the last ten years regarding the application of CDs in general as CSs in CE, reviews in which CD dual system are mentioned as an interesting and useful option. We can mention here the reviews published 
by Rezanka et al. [13] and Saz et al. [16]. Generalized mathematical models of separation in both single and dual CD systems were proposed by Dubský et al. [60,65,69]. Also, a review regarding theoretical models used to explain separation mechanism, published by Müllerová et al. [22] is worth mention.

It is interesting to mention that initial works involving the use of $C D$ dual system in CE enantioseparations focused mainly on the analysis of model compounds with particular structural and electrophoretic properties in order to develop theoretical models used to characterize the influence of chiral discrimination ability and electrophoretic mobility of the two CDs on the overall selectivity of the enantiomeric separation. As information about separation mechanism in dual CD system was clarified, research direction changed, and studies focused mainly on the application of dual CD systems on the enantiomer separation of specific chiral analytes; the use of dual CD systems for the verification of enantiomeric purity, quantitative analysis from pharmaceutical formulations or pharmacokinetic studies have been reported.

In $C E$, the right selection of the optimum $C D$ to be used to achieve chiral resolution is the essential step in method development. When the use of a single CD does not provide enantioresolution, the addition of a second $C D$ may generate separation. In the case of dual CD systems usually a combination of an anionic CD (e.g., SBE- $\beta-C D, C M-\beta-C D, S-\beta-C D)$ with a neutral $C D$ (e.g., methylated- $\beta-C D, H P-\beta-C D)$ is used. It is a fact that many analytes have basic character at an acidic $\mathrm{pH}$, consequently, are positively charged and will have a higher affinity towards negatively charged CDs, increasing enantiorecognition capability. The use of dual CD systems is extremely useful in the case of analytes in uncharged form; in this situation it is preferable that the charged CDs should have no enantioselectivity towards the analyte or exhibit a chiral recognition pattern opposite to the neutral CD.

Based on the described separation mechanism, the two enantiomers of a chiral analyte under interaction with a dual CD system are likely to differ in their mobilities, compared with single CD systems where the mobilities are likely to be the same. Although generally different distribution constants between the two enantiomers and CDs in single CD system dictates enantioseparation, in dual $\mathrm{CD}$ systems additional electrophoretic enantioselective mechanisms resulting from different electrophoretic mobilities of the enantiomer-CD complexes play an important role in separation. Dual CD systems are more selective than single $\mathrm{CD}$ systems due to this additional separation mechanism.

The use of dual CDs system can be a useful tool in the enantioseparation of pharmaceuticals, offering good perspectives and high potential, as novel dual systems are continuously developed and applied in diverse analytical fields.

Author Contributions: Conceptualization, G.H. and L.A.P.; methodology, G.H.; writing—original draft preparation, G.H. and L.A.P.; writing - review and editing, G.T.; project administration, G.H.; funding acquisition, H.K. All authors have read and agreed to the published version of the manuscript.

Funding: This research was funded by a project collaboration between Medical and Pharmaceutical Section of the Transylvanian Museum Society and Faculty of Pharmacy of Semmelweis University Hungary (contract nr. 20.2/2018/P.2/EMEOGYSZ and 106.2/2020) (H.K.). This work was supported by the János Bolyai Research Scholarship of the Hungarian Academy of Sciences (G.T.). The financial support from Bolyai + New National Excellence Program (UNKP- 20- 5) of the Ministry for Innovation and Technology is highly appreciated (G.T.). The financial support from the National Talent Program (NTP-NFTÖ-20-B-0072) is highly appreciated (L.A.P.).

Institutional Review Board Statement: Not applicable.

Informed Consent Statement: Not applicable.

Conflicts of Interest: The authors declare no conflict of interest. 


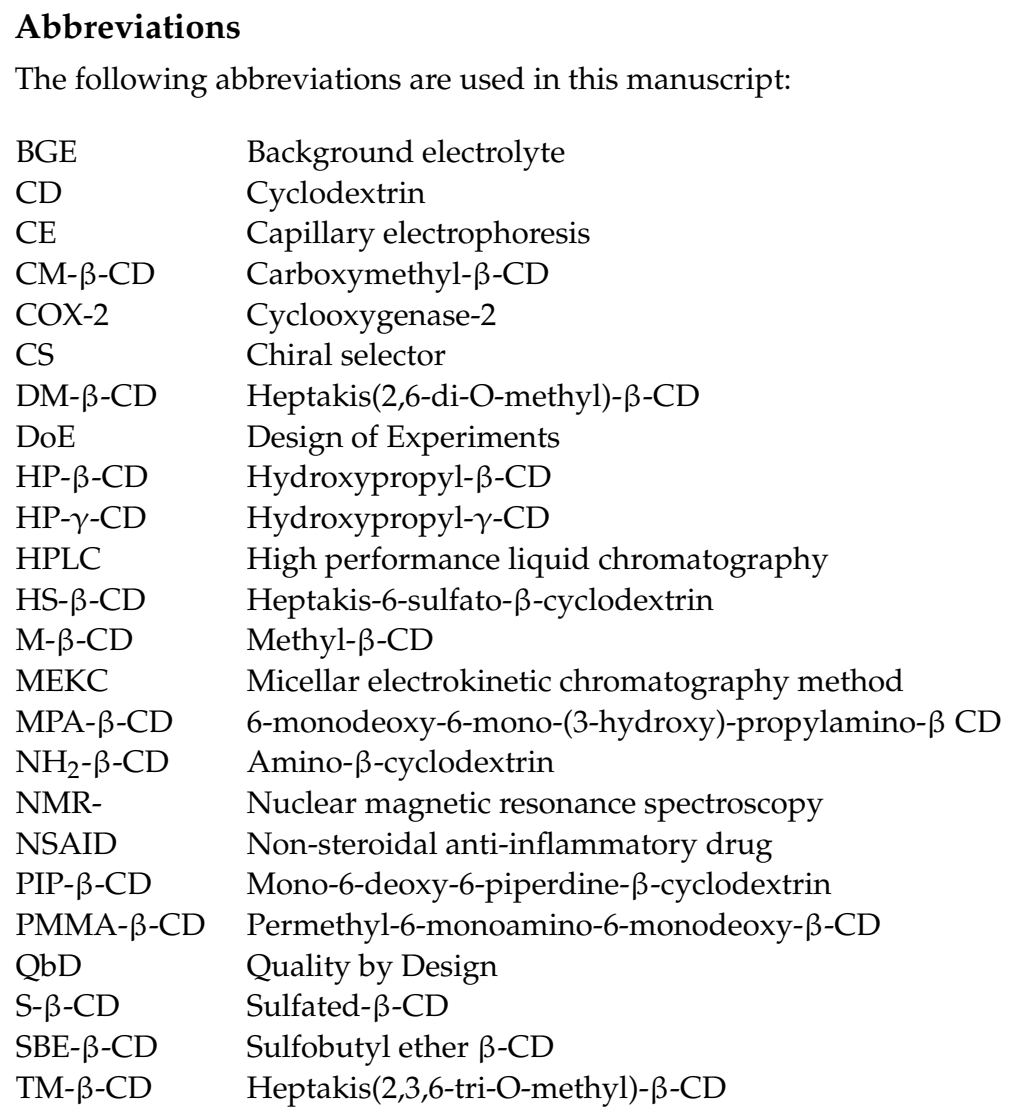

\section{References}

1. Brooks, W.H.; Guida, W.C.; Daniel, K.G. The significance of chirality in drug design and development. Curr. Top Med. Chem. 2011, 11, 760-770. [CrossRef]

2. De Camp, W.H. Chiral drugs: The FDA perspective on manufacturing and control. J. Pharm. Biomed. Anal. 1993, 11, 167-1172. [CrossRef]

3. Gübitzm, G.; Schmid, M.G. Chiral separation principles in chromatographic and electromigration techniques. Mol. Biotechnol. 2006, 32, 159-180. [CrossRef]

4. Zhang, Y.; Yao, S.; Zeng, H.; Song, H. Chiral separation of pharmaceuticals by high performance liquid chromatography. Curr. Pharm. Anal. 2010, 6, 114-130. [CrossRef]

5. He, L.; Beesley, T.E. Applications of enantiomeric gas chromatography: A review. J. Liq. Chrom. Relat. Tech. 2005, 28 , 1075-1114. [CrossRef]

6. Martens, J.; Bhushan, R. Importance of enantiomeric purity and its control by thin-layer chromatography. J. Pharm. Biomed. Anal. 1990, 8, 259-269. [CrossRef]

7. De Klerck, K.; Mangelings, D.; Vander Heyden, Y. Supercritical fluid chromatography for the enantioseparation of pharmaceuticals. J. Pharm. Biomed. Anal. 2012, 69, 77-92. [CrossRef] [PubMed]

8. Wenzel, T.J. Determination of Enantiomeric Purity and Absolute Configuration by NMR Spectroscopy. In Stereoselective Synthesis of Drugs and Natural Products; John Wiley \& Sons, Inc.: Hoboken, NJ, USA, 2013; pp. 1-24.

9. Flack, H.D.; Bernardinelli, G. The use of X-ray crystallography to determine absolute configuration. Chirality 2008, 20, 681-690. [CrossRef]

10. Fanali, S.; Chankvetadze, B. Some thoughts about enantioseparation in capillary electrophoresis. Electrophoresis 2019, 40, $2420-2437$. [CrossRef]

11. Reminek, R.; Foret, H. Capillary electrophoretic methods for quality control analysis of pharmaceuticals: A review. Electrophoresis 2021, 42, 19-37. [CrossRef]

12. Chankvetadze, B. Enantiomer migration order in chiral capillary electrophoresis. Electrophoresis 2002, 23, 4022-4035. [CrossRef] [PubMed]

13. Rezanka, P.; Navrátilová, K.; Rezanka, M.; Král, V.; Sýkora, D. Application of cyclodextrins in chiral capillary electrophoresis. Electrophoresis 2014, 35, 2701-2721. [CrossRef] [PubMed]

14. Escuder-Gilabert, L.; Martín-Biosca, Y.; Medina-Hernández, M.J.; Sagrado, S. Cyclodextrins in capillary electrophoresis: Recent developments and new trends. J. Chromatogr. A 2014, 1357, 2-23. [CrossRef] [PubMed] 
15. Chankvetadze, L.; Servais, A.C.; Fillet, M.; Salgado, A.; Crommen, J.; Chankvetadze, B. Comparative enantioseparation of talinolol in aqueous and non-aqueous capillary electrophoresis and study of related selector-selectand interactions by nuclear magnetic resonance spectroscopy. J. Chromatogr. A 2012, 1267, 206-216. [CrossRef]

16. Saz, J.M.; Marina, M.L. Recent advances on the use of cyclodextrins in the chiral analysis of drugs by capillary electrophoresis. J. Chromatogr. A 2016, 1467, 79-94. [CrossRef]

17. Fillet, M.; Hubert, P.; Crommen, J. Method development strategies for the enantioseparation of drugs by capillary electrophoresis using cyclodextrins as chiral additives. Electrophoresis 1998, 19, 2834-2840. [CrossRef]

18. Wren, S.A.C.; Rowe, R.C. Theoretical aspects of chiral separation in capillary electrophoresis. J. Chromatogr. A 1992, 603, $235-241$. [CrossRef]

19. Fillet, M.; Hubert, P.; Crommen, J. Enantiomeric separations of drugs using mixtures of charged and neutral cyclodextrins. J. Chromatogr. A 2000, 875, 123-134. [CrossRef]

20. Dubský, P.; Dvořák, M.; Ansorge, M. Affinity capillary electrophoresis: The theory of electromigration. Anal. Bioanal. Chem. 2016, 408, 8623-8641. [CrossRef] [PubMed]

21. Chankvetadze, B. Contemporary theory of enantioseparations in capillary electrophoresis. J. Chromatogr. A 2018, 1567, 2-25. [CrossRef]

22. Müllerová, L.; Dubský, P.; Gaš, B. Twenty years of development of dual and multi-selector models in capillary electrophoresis: A review. Electrophoresis 2014, 35, 2688-2700. [CrossRef]

23. Lurie, I.S.; Klein, R.F.; Dal Cason, T.A.; LeBelle, M.J.; Brenneisen, R.; Weinberger, R.E. Chiral resolution of cationic drugs of forensic interest by capillary electrophoresis with mixtures of neutral and anionic cyclodextrins. Anal. Chem. 1994, 66, 4019-4026. [CrossRef]

24. Anigbogu, V.C.; Cooper, C.L.; Sepaniak, M.J. Separation of stereoisomers of aminoglutethimide using three capillary electrophoretic techniques. J. Chromat. A 1995, 2, 343-349. [CrossRef]

25. Lelièvre, F.; Gareil, P.; Bahaddi, Y.; Galons, H. Intrinsic selectivity in capillary electrophoresis for chiral separations with dual cyclodextrin systems. Anal. Chem. 1997, 69, 393-401. [CrossRef]

26. Fillet, M.; Hubert, P.; Crommen, J. Enantioseparation of nonsteroidal anti-inflammatory drugs by capillary electrophoresis using mixtures of anionic and uncharged beta-cyclodextrins as chiral additives. Electrophoresis 1997, 18, 1013-1018. [CrossRef]

27. Fillet, M.; Fotsing, L.; Crommen, J. Enantioseparation of uncharged compounds by capillary electrophoresis using mixtures of anionic and neutral $\beta$-cyclodextrin derivatives. J. Chromatogr. A 1998, 817, 113-119. [CrossRef]

28. Fillet, M.; Chankvetadze, B.; Crommen, J.; Blaschke, G. Designed combination of chiral selectors for adjustment of enantioseparation selectivity in capillary electrophoresis. Electrophoresis 1999, 20, 2691-2697. [CrossRef]

29. Fillet, M.; Fotsing, L.; Bonnard, J.; Crommen, J. Stereoselective determination of S-naproxen in tablets by capillary electrophoresis. J. Pharm. Biomed. Anal. 1998, 18, 799-805. [CrossRef]

30. Meyring, M.; Chankvetadze, B.; Blaschke, G. Enantioseparation of thalidomide and its hydroxylated metabolites using capillary electrophoresis with various cyclodextrins and their combinations as chiral buffer additives. Electrophoresis 1999, 20, $2425-2431$. [CrossRef]

31. Meyring, M.; Mühlenbrock, C.; Blaschke, G. Investigation of the stereoselective in vitro biotransformation of thalidomide using a dual cyclodextrin system in capillary electrophoresis. Electrophoresis 2000, 21, 3270-3279. [CrossRef]

32. Blaschke, G.; Meyring, M.; Mühlenbrock, C.; Chankvetadze, B. Recent results of biotransformation of drugs: Investigation of the in vitro biotransformation of thalidomide using a dual cyclodextrin system in capillary electrophoresis. Farmaco 2002, 57, 551-554. [CrossRef]

33. Abushoffa, A.M.; Fillet, M.; Hubert, P.; Crommen, J. Prediction of selectivity for enantiomeric separations of uncharged compounds by capillary electrophoresis involving dual cyclodextrin systems. J. Chromatogr. A 2002, 948, 321-329. [CrossRef]

34. Abushoffa, A.M.; Fillet, M.; Servais, A.C.; Hubert, P.; Crommen, J. Enhancement of selectivity and resolution in the enantioseparation of uncharged compounds using mixtures of oppositely charged cyclodextrins in capillary electrophoresis. Electrophoresis 2003, 24, 343-350. [CrossRef]

35. Pérez-Maseda, C.; Calvet, C.; Cuberes, R.; Frigola, J. Determination of enantiomeric purity of a novel COX-2 anti-inflammatory drug by capillary electrophoresis using single and dual cyclodextrin systems. Electrophoresis 2003, 24, 1416-1421. [CrossRef] [PubMed]

36. Tábi, T.; Magyar, K.; Szöko, E. Chiral characterization of deprenyl-N-oxide and other deprenyl metabolites by capillary electrophoresis using a dual cyclodextrin system in rat urine. Electrophoresis 2003, 24, 2665-2673. [CrossRef] [PubMed]

37. Lin, X.; Hou, W.; Zhu, C. Enantiomer separation of miconazole by capillary electrophoresis with dual cyclodextrin systems. Anal. Sci. 2003, 19, 1509-1512. [CrossRef] [PubMed]

38. Beaufour, M.; Morin, P.; Ribet, J.P. Chiral separation of the four stereoisomers of a novel antianginal agent using a dual cyclodextrin system in capillary electrophoresis. J. Sep. Sci. 2005, 28, 529-533. [CrossRef]

39. Lorin, M.; Delépée, R.; Morin, P.; Ribet, J.P. Quantification of very low enantiomeric impurity of efaroxan using a dual cyclodextrin system by capillary electrophoresis. Anal. Chim. Acta 2007, 5, 139-145. [CrossRef]

40. Chu, B.L.; Guo, B.; Zuo, H.; Wang, Z.; Lin, J.M. Simultaneous enantioseparation of antiparkinsonian medication rotigotine and related chiral impurities by capillary zone electrophoresis using dual cyclodextrin system. J. Pharm. Biomed. Anal. 2008, 46, 854-859. [CrossRef] 
41. Sungthong, B.; Jác, P.; Scriba, G.K. Development and validation of a capillary electrophoresis method for the simultaneous determination of impurities of escitalopram including the R-enantiomer. J. Pharm. Biomed. Anal. 2008, 46, 959-965. [CrossRef]

42. Jamali, B.; Bjørnsdottir, I.; Cornett, C.; Honoré Hansen, S. Investigation of a dual CD chiral CE system for separation of glitazone compounds. Electrophoresis 2009, 30, 2853-2861. [CrossRef] [PubMed]

43. Wongwan, S.; Sungthong, B.; Scriba, G.K. CE assay for simultaneous determination of charged and neutral impurities in dexamphetamine sulfate using a dual CD system. Electrophoresis 2010, 31, 1475-1481. [CrossRef] [PubMed]

44. Lipka, E.; Danel, C.; Yous, S.; Bonte, J.P.; Vaccher, C. Dual CD system in capillary electrophoresis for direct separation of the four stereoisomers of agonist and antagonist melatoninergic ligands. Electrophoresis 2010, 31, 1529-1532. [CrossRef]

45. Wagner, Z.; Tábi, T.; Jakó, T.; Zachar, G.; Csillag, A.; Szökő, E. Chiral separation and determination of excitatory amino acids in brain samples by CE-LIF using dual cyclodextrin system. Anal. Bioanal. Chem. 2012, 404, 2363-2368. [CrossRef]

46. Sohajda, T.; Szakács, Z.; Szente, L.; Noszál, B.; Béni, S. Chiral recognition of imperanene enantiomers by various cyclodextrins: A capillary electrophoresis and NMR spectroscopy study. Electrophoresis 2012, 33, 1458-1464. [CrossRef] [PubMed]

47. Wan Ibrahim, W.A.; Abd Wahib, S.M.; Hermawan, D.; Sanagi, M.M.; Aboul-Enein, H.Y. Separation of selected imidazole enantiomers using dual cyclodextrin system in micellar electrokinetic chromatography. Chirality 2013, 25, 328-335. [CrossRef]

48. Lipka, E.; Landagaray, E.; Ettaoussi, M.; Yous, S.; Vaccher, C. Enhanced detection for determination of enantiomeric purity of novel agomelatine analogs by EKC using single and dual cyclodextrin systems. Electrophoresis 2014, 35, 2785-2792. [CrossRef]

49. Yu, J.; Zhao, Y.; Song, J.; Guo, X. Enantioseparation of meptazinol and its three intermediate enantiomers by capillary electrophoresis using a new cationic $\beta$-cyclodextrin derivative in single and dual cyclodextrin systems. Biomed. Chromatogr. 2014, 28, 868-874. [CrossRef]

50. Znaleziona, J.; Fejős, I.; Ševčík, J.; Douša, M.; Béni, S.; Maier, V. Enantiomeric separation of tapentadol by capillary electrophoresisstudy of chiral selectivity manipulation by various types of cyclodextrins. J. Pharm. Biomed. Anal. 2015, 105, 10-16. [CrossRef]

51. Orlandini, S.; Pasquini, B.; Del Bubba, M.; Pinzauti, S.; Furlanetto, S. Quality by design in the chiral separation strategy for the determination of enantiomeric impurities: Development of a capillary electrophoresis method based on dual cyclodextrin systems for the analysis of levosulpiride. J. Chromatogr. A 2015, 1380, 177-185. [CrossRef] [PubMed]

52. Melani, F.; Pasquini, B.; Caprini, C.; Gotti, R.; Orlandini, S.; Furlanetto, S. Combination of capillary electrophoresis, molecular modeling, and NMR to study the enantioselective complexation of sulpiride with double cyclodextrin systems. J. Pharm. Biomed. Anal. 2015, 114, 265-271. [CrossRef]

53. Szabó, Z.I.; Tóth, C.; Hancu, G.; Muntean, D.L. Simultaneous chiral separation of four H1-antihistamines by capillary zone electrophoresis using a dual cyclodextrin system. Chromatographia 2015, 78, 1377-1384. [CrossRef]

54. Nováková, Z.; Pejchal, V.; Fischer, J.; Česla, P. Chiral separation of benzothiazole derivatives of amino acids using capillary zone electrophoresis. J. Sep. Sci. 2017, 40, 798-803. [CrossRef]

55. Delplanques, T.; Boulahjar, R.; Charton, J.; Houze, C.; Howsam, M.; Servais, A.C.; Fillet, M.; Lipka, E. Single and dual cyclodextrins systems for the enantiomeric and diastereoisomeric separations of structurally related dihydropyridone analogues. Electrophoresis 2017, 38, 1922-1931. [CrossRef] [PubMed]

56. Sandbaumhüter, F.A.; Theurillat, R.; Thormann, W. Separation of hydroxynorketamine stereoisomers using capillary electrophoresis with sulfated $\beta$-cyclodextrin and highly sulfated $\gamma$-cyclodextrin. Electrophoresis 2017, 38, 1878-1885. [CrossRef] [PubMed]

57. Papp, L.A.; Hancu, G.; Gyéresi, Á.; Kelemen, H.; Szabó, Z.I.; Noszál, B.; Dubský, P.; Tóth, G. Chiral separation of lansoprazole and rabeprazole by capillary electrophoresis using dual cyclodextrin systems. Electrophoresis 2019, 40, 2799-2805. [CrossRef] [PubMed]

58. Harnisch, H.; Scriba, G.K.E. Capillary electrophoresis method for the determination of (R)-dapoxetine, (3S)-3-(dimethylamino)-3phenyl-1-propanol, (S)-3-amino-3-phenyl-1-propanol and 1-naphthol as impurities of dapoxetine hydrochloride. J. Pharm. Biomed. Anal. 2019, 162, 257-263. [CrossRef]

59. Krait, S.; Heuermann, M.; Scriba, G.K.E. Development of a capillary electrophoresis method for the determination of the chiral purity of dextromethorphan by a dual selector system using quality by design methodology. J. Sep. Sci. 2018, 41, 1405-1413. [CrossRef] [PubMed]

60. Dubský, P.; Svobodová, J.; Gas, B. Model of CE enantioseparation systems with a mixture of chiral selectors. Part I. Theory of migration and interconversion. J. Chromatogr. B Analyt. Technol. Biomed. Life Sci. 2008, 875, 30-34. [CrossRef]

61. Casado, N.; Saz, J.M.; García, M.Á.; Marina, M.L. Modeling-based optimization of the simultaneous enantiomeric separation of multicomponent mixtures of phenoxy acid herbicides using dual cyclodextrin systems by capillary electrophoresis. J. Chromatogr. A 2020, 1610, 460552. [CrossRef]

62. Lurie, I.S. Separation selectivity in chiral and achiral capillary electrophoresis with mixed cyclodextrins. J. Chromatogr. A 1997, 792, 297-307. [CrossRef]

63. de Koster, N.; Clark, C.P.; Kohler, I. Past, present, and future developments in enantioselective analysis using capillary electromigration techniques. Electrophoresis 2021, 42, 38-57. [CrossRef]

64. Salgado, A.; Chankvetadze, B. Applications of nuclear magnetic resonance spectroscopy for the understanding of enantiomer separation mechanisms in capillary electrophoresis. J. Chromatogr. A 2016, 1467, 95-144. [CrossRef]

65. Dubský, P.; Müllerová, L.; Dvořák, M.; Gaš, B. Generalized model of electromigration with 1:1 (analyte:selector) complexation stoichiometry: Part I. Theory. J. Chromatogr. A 2015, 1384, 142-146. [CrossRef] 
66. Klein-Júnior, L.C.; Mangelings, D.; Vander Heyden, Y. Experimental design methodologies for the optimization of chiral separations: An overview. Methods Mol. Biol. 2019, 1985, 453-478. [CrossRef]

67. Servais, A.C.; Fillet, M. Application of dual-cyclodextrin systems in capillary electrophoresis enantioseparations. Methods Mol. Biol. 2019, 1985, 357-364. [CrossRef]

68. Krait, S.; Konjaria, M.L.; Scriba, G.K.E. Advances of capillary electrophoresis enantioseparations in pharmaceutical analysis (2017-2020). Electrophoresis 2021. [CrossRef]

69. Dubský, P.; Svobodová, J.; Tesarová, E.; Gas, B. Model of CE enantioseparation systems with a mixture of chiral selectors. Part II. Determination of thermodynamic parameters of the interconversion in chiral and achiral environments separately. J. Chromatogr. B Analyt. Technol. Biomed. Life Sci. 2008, 875, 35-41. [CrossRef] 